\title{
An Evaluation of the Operational Performance and Profitability of the U.S. Airlines
}

\author{
Carol C. Huang ${ }^{1}$ (i) $\cdot$ Chris C. Hsu² ${ }^{2} \cdot$ Emilio Collar $^{3}$ (D)
}

Received: 26 February 2021 / Accepted: 13 July 2021 / Published online: 4 August 2021

(c) Global Institute of Flexible Systems Management 2021

\begin{abstract}
Since 2008, a series of mega-mergers has dramatically changed the U.S. airline industry. Despite the presence of fewer airlines in the market, the competition remains intense, which forces airlines to continually search for ways to increase their efficiency to maintain survival and financial sustainability. To evaluate airline performance and disentangle the causes of inefficiency, this paper applied a two-stage network data envelopment analysis approach and a truncated regression to investigate the performance of nine U.S.-based airlines from 2015 to 2019. Our empirical results reveal that during the sample period, airlines' operating efficiency steadily improved, but the efficiency in the profitability stage stagnated. Therefore, strategic resource allocations are needed for airlines to see further advances in their overall efficiency. On average, airlines operating in the low-cost business model yielded higher efficiency scores than their peers operating in the full-service framework. While an airline's size, measured in terms of total assets, has a positive influence on operating efficiency, a larger number of full-time employee equivalents hinders efficiency outcomes, which indicates the importance of enhancing labor efficiency among carriers.
\end{abstract}

Keywords Network data envelopment analysis · Airline industry · Operational performance $\cdot$ Financial performance

JEL Classification C60 - L93

\section{Introduction}

The airline industry is one of the essential service sectors that support the growth of the global economy. According to the International Air Transport Association (IATA), in 2019, the industry contributed $\$ 2.7$ trillion in GDP and carried more than 4 billion passengers and 60 million cargo tons.

Carol C. Huang

huangc@wcsu.edu

Chris C. Hsu

chsu@york.cuny.edu

Emilio Collar

collare@wcsu.edu

1 Department of Finance, Western Connecticut State University, Danbury, USA

2 Department of Accounting and Finance, CUNY Aviation Institute, York College, The City University of New York, New York, USA

3 Department of Management Information Systems, Western Connecticut State University, Danbury, USA
While demands for air travel and air freight services have been robust, the industry's profit margins remain thin and volatile due to its unique business characteristics.

Known as a labor- and capital-intensive industry, the airline industry's labor and operational costs are high (Vasigh et al., 2015). The industry's high operating leverage makes its profits very sensitive to fluctuations in air-traffic demand. Furthermore, air transport demand is occasionally disrupted by external shocks such as global economic slowdowns (Chen et al., 2017; Sadi \& Henderson, 2000), epidemics (Dube et al., 2021; Sun et al., 2021), natural disasters (Janić, 2019), and terrorism (Corbet et al., 2019; Goodrich, 2002; Inglada \& Rey, 2004; Mitra et al., 2018). When disruptions occur, airlines' existing financial commitments remain despite decreased revenues. Moreover, reducing excess capacity in the near term is not an option as many passenger travels are booked months in advance. Therefore, the airline industry consistently faces various challenges. In recent years, the industry has recognized its vital role in global climate change and committed to more sustainable 
business practices ${ }^{1}$ (IATA, 2020), which call for additional financial resources to implement new initiatives. Thus, to foster airlines' long-term growth and financial sustainability, airlines are always seeking ways to improve their operational and financial efficiency to maintain their competitiveness and survival.

The enactment of the Airline Deregulation Act of 1978 brought more competition to the U.S. airline industry. Today, the market is composed of airlines operating under different business models: (1) full-service or network carriers, whose hub-and-spoke operations offer a comprehensive network with a variety of services to choose from; (2) low-cost carriers, who carry fewer types of aircraft offering point-to-point service; and (3) regional airlines, who operate on a smaller scale with smaller aircraft. Given the challenging environment in which they operate, to maintain their presence, airlines have pursued various cost savings strategies such as outsourcing labor-intensive services, joining alliances, establishing code-sharing agreements with peers, upgrading their technological infrastructure, etc. Nevertheless, the return on invested capital remains lower than their cost of capital even in good years, suggesting that shareholders' value has long been eroded (Pearce, 2012). Over the years, the industry has experienced cyclical financial performance, and more than 100 airlines have filed for bankruptcy since 1979 (Kumar, 2012). Since the early 2000s, the U.S. airline industry has witnessed several mega-mergers, i.e., the merger of Northwest Airlines and Delta Air Lines in 2008, the merger of United Airlines and Continental Airlines in 2010, the merger of Southwest Airlines with AirTran Airways in 2011, and the merger of American Airlines and US Airways in 2013. These mergers have led to a remarkable change in the U.S. airline market; and the four acquirers, Delta Air Lines, United Airlines, American Airlines, and Southwest Airlines, are now the largest carriers owning more than $80 \%$ of the market share combined (Huang et al., 2019). While being large helps to capture economies of scale and is seen as a prerequisite for continued success (Heshmati \& Kim, 2016), airlines also need to weigh the benefits against increased operating costs due to expanded size.

This study aims to investigate the operational and financial performance of nine major U.S.-based airlines from 2015 to 2019. In retrospect, 2015-2019 was a relatively stable period without significant disruptions for the U.S. air market. Therefore, this period offers an excellent opportunity to examine the fundamentals contributing to airlines'

\footnotetext{
1 According to Sledsens (1998), sustainable aviation is defined as "basic mobility to all citizens without damaging nature and the environment". Karakoc et al. (2019) identified that there are three pillars relevant to the aviation industry, including economic, social, and environmental issues; with the environmental aspects being the current major focus among airlines.
}

operational and financial performance without complications from exogenous influences. Specifically, this paper used an input-oriented two-stage network data envelopment analysis (DEA) to identify the sources of deficiency in each stage of activity. In this study, the first stage is designed to analyze whether airlines can effectively use input resources to generate revenue; and in the second stage, attention is placed on how effectively airlines can convert revenues into measurable financial outcomes. Applying a two-stage network model is crucial in this line of study because such a model helps address the interaction between different stages of corporate activities, which are mostly interdependent. A bootstrapped truncated regression model proposed by Simar and Wilson (2007) was used to examine the systematic reasons for the inefficiency in the operations and resource allocation.

The remainder of the paper is organized as follows. Literature Review discusses the literature on airline efficiency. Research Method and Data describes the data and the designs of empirical models. Section Empirical Results discusses the empirical findings, and Sect. Conclusion concludes the study.

\section{Literature Review}

As a highly regulated industry, the airline industry has always attracted considerable attention from policymakers, market practitioners, and consumers. Empirically, airline performance is measured through the analysis of airlines' efficiency. The focus of existing studies on airline efficiency, in general, falls into the following categories: the study of airlines' performance in a specific country or region; the investigation of how geographical differences affect the realized efficiency metrics; and the examination of how differences in business models, firm-specific characteristics, and strategic management influence airlines' performance. Table 1 summarizes some recent studies on airline efficiency.

The majority of studies on airline efficiency focus on airlines based in the U.S. and Europe. For example, by adopting DEA and Malmquist productivity methods, Greer (2008) analyzed airline productivity in the U.S. from 2000 to 2004 and documented that the productivity gains during this period were primarily achieved by relatively inefficient carriers converging toward higher efficiency. Barros and Peypoch (2009) examined a group of European airlines from 2000 to 2005 using a two-stage DEA approach. They revealed a trend of productivity growth over the years, and the demographic factors of an airline's home country play a significant role in the airline's efficiency performance. Moreover, the adoption of a low-cost business model promotes airline efficiency in the selected sample. However, in a later study using a longer sample period from 2000 to 2011, Barros and Couto (2013) found that most European 
Table 1 Summary of recent studies on airline efficiency

\begin{tabular}{|c|c|c|c|}
\hline Author(s) & Sample & Period & Methodology/Variable \\
\hline Greer (2008) & 8 US airlines & $2000-2004$ & $\begin{array}{l}\text { DEA and Malmquist productivity index } \\
\text { Inputs: labor, fuel, passenger seating capacity } \\
\text { Output: available seat mile }\end{array}$ \\
\hline Barros and Peypoch (2009) & 27 European airlines & 2000-2005 & $\begin{array}{l}\text { Two-stage DEA model and truncated bootstrapped regression } \\
\text { Inputs: employees, operational cost, planes } \\
\text { Outputs: revenue passenger kilometer, earnings before interest and taxes }\end{array}$ \\
\hline Merkert and Hensher (2011) & 58 international airlines & 2007-2009 & $\begin{array}{l}\text { Two-stage DEA model } \\
\text { Inputs: full-time employee, available tonne kilometer, full-time } \\
\text { employee_price, available tonne kilometer_price } \\
\text { Outputs: revenue passenger kilometer, revenue tonne kilometre }\end{array}$ \\
\hline Zhu (2011) & 21 international airlines & $2007-2008$ & $\begin{array}{l}\text { Two-stage centralized DEA model } \\
\text { Inputs: cost per available seat mile, salaries, wages, \& benefits per avail- } \\
\text { able seat mile, fuel expense per available seat mile, fuel cost, gallon } \\
\text { used } \\
\text { Intermediates: load factor, fleet size } \\
\text { Outputs: revenue passenger mile, passenger revenue }\end{array}$ \\
\hline Gramani (2012) & 4 international airlines & 1997-2006 & $\begin{array}{l}\text { Two-phase DEA model } \\
\text { 1st phase inputs: aircraft fuel, wages, salaries and benefits, CASM } \\
\text { 1st phase output: revenue passenger mile } \\
\text { 2nd phase input: 1/efficiency score } \\
\text { 2nd phase outputs: flight revenue, flight income }\end{array}$ \\
\hline Merkert and Morrell (2012) & 66 international airlines & 2007-2009 & $\begin{array}{l}\text { DEA model } \\
\text { Inputs: labor, available tonne kilometer } \\
\text { Outputs: revenue passenger kilometers, revenue tonne kilometer, revenue }\end{array}$ \\
\hline Lu et al. (2012) & 30 US airlines & 2006 & $\begin{array}{l}\text { Two-stage DEA model } \\
\text { Inputs: full-time employee, fuel, seats, flight, maintenance expense, cost } \\
\text { of ground property and equipment } \\
\text { Intermediates: available seat mile, available ton mile } \\
\text { Outputs: revenue passenger mile, non-passenger revenue }\end{array}$ \\
\hline Pires and Fernandes (2012) & 42 international airlines & $2001-2002$ & $\begin{array}{l}\text { DEA model and Malmquist index } \\
\text { Input: financial leverage } \\
\text { Outputs: firm size, tangibility of assets, intangible assets }\end{array}$ \\
\hline Barros et al. (2013) & 11 US airlines & $1998-2010$ & $\begin{array}{l}\text { B-Convex model } \\
\text { Inputs: total cost, full-time employee, gallons used } \\
\text { Outputs: total revenue, revenue passenger mile, load factor }\end{array}$ \\
\hline Barros and Couto (2013) & 23 European airlines & 2000-2011 & $\begin{array}{l}\text { Luenberger productivity indicator } \\
\text { Inputs: employees, operating cost, available seat kilometer } \\
\text { Outputs: revenue passenger kilometer, revenue tonne kilometre }\end{array}$ \\
\hline Arjomandi and Seufert (2014) & 48 international airlines & $2007-2010$ & $\begin{array}{l}\text { Bootstrapped DEA model } \\
\text { Inputs: labor, capital } \\
\text { Outputs: available tonne kilometer, } \mathrm{CO}_{2} \text { emission }\end{array}$ \\
\hline Chang et al. (2014) & 27 international airlines & 2010 & $\begin{array}{l}\text { Slacks-based measure DEA model } \\
\text { Inputs: available ton kilometer, employees } \\
\text { Outputs: revenue ton kilometer, profits, and carbon emissions }\end{array}$ \\
\hline Lee and Worthington (2014) & 42 international airlines & 2006 & $\begin{array}{l}\text { DEA model and bootstrapped truncated regression } \\
\text { Inputs: kilometers flown, employees, total assets } \\
\text { Output: available ton kilometre }\end{array}$ \\
\hline Wu and Liao (2014) & 38 international airlines & 2012 & $\begin{array}{l}\text { Integrated DEA-BSC model } \\
\text { Inputs: material, energy, capital, passenger, revenue passenger kilometer, } \\
\text { labor, other operating expenses } \\
\text { Outputs: operating revenue, return on assets, return on investment, net } \\
\text { income }\end{array}$ \\
\hline Mallikarjun (2015) & 27 US airlines & 2012 & $\begin{array}{l}\text { Unoriented network DEA model } \\
\text { Input: operating expenses } \\
\text { Output: operating revenue } \\
\text { Intermediates: available seat mile, revenue passenger mile } \\
\text { Site characteristics: fleet size, destinations }\end{array}$ \\
\hline
\end{tabular}


Table 1 (continued)

\begin{tabular}{|c|c|c|c|}
\hline Author(s) & Sample & Period & Methodology/Variable \\
\hline Duygun et al. (2016) & 87 European airlines & $2000-2010$ & $\begin{array}{l}\text { Network DEA } \\
\text { Inputs: flight capital, labor, materials } \\
\text { Output: revenue ton kilometer } \\
\text { Intermediate: revenue ton kilometer /load factor }\end{array}$ \\
\hline Choi (2017) & 14 US airlines & 2006-2015 & $\begin{array}{l}\text { Bootstrapped DEA and truncated bootstrapped regression } \\
\text { Input: cost per available seat mile } \\
\text { Outputs: revenue per available seat mile, yield, load factor }\end{array}$ \\
\hline Chen et al. (2018) & 11 Chinese airlines & 2006-2016 & $\begin{array}{l}\text { Malmquist productivity index } \\
\text { Inputs: employees, number of airplanes, fuel (in metric tons) } \\
\text { Outputs: revenue ton kilometer, revenue passenger kilometer }\end{array}$ \\
\hline Kuljanin et al. (2019) & 17 European airlines & 2008,2012 & $\begin{array}{l}\text { Fuzzy theory-based DEA model } \\
\text { Inputs: employees, aircraft, cost per available seat kilometer, employee } \\
\text { cost per available seat kilometer, available seat kilometer, delay } \\
\text { Outputs: aircraft per employee, passenger per employee, revenue passen- } \\
\text { ger kilometer, load factor, passengers, operating revenue, destinations }\end{array}$ \\
\hline Yu et al. (2019) & 13 international airlines & $2008-2015$ & $\begin{array}{l}\text { Dynamic network DEA model } \\
\text { Inputs: employees, aircraft } \\
\text { Outputs: revenue passenger kilometer, revenue tonne kilometer } \\
\text { Intermediates: departures, flying hours } \\
\text { Carry-over: destinations }\end{array}$ \\
\hline Zhang et al. (2019) & 9 international airlines & 2006-2016 & $\begin{array}{l}\text { Two-stage network DEA model } \\
\text { Inputs for 1st stage: cost per available seat mile (excluding fuel), employ- } \\
\text { ees, fuel cost per available seat mile } \\
\text { Intermediate: revenue passenger kilometer } \\
\text { Output for 1st stage: sales } \\
\text { Inputs for 2nd stage: weighted average cost of capital, short interest ratio, } \\
\text { market capitalization } \\
\text { Outputs for 2nd stage: net income, capital gain yield, return of equity }\end{array}$ \\
\hline
\end{tabular}

airlines did not achieve productivity growth except for a few low-cost carriers. Mallikarjun (2015) investigated U.S. airlines' performance in 2012 using an unoriented network DEA model and revealed that major U.S. airlines demonstrated higher efficiency in managing operating expenses and revenue generation than national U.S. airlines. Using data from 87 European airlines and the network DEA model, Duygun et al. (2016) concluded that most of these European airlines' inefficiencies came from the first stage of production. They also found that low-cost carriers are more efficient than full-service network carriers because low-cost carriers were able to adapt more quickly to changes in market demand. Choi (2017) studied the changes in U.S. domestic airlines for 2006-2015 using a bootstrapping DEA model and found that network legacy carriers have higher efficiency scores than carriers operating under low-cost business models. The impacts of M\&As between U.S. carriers are mixed. Applying the Malmquist productivity index and the DEA model, Chen et al. (2018) analyzed the productivity of Chinese airlines for 2006-2016. They documented that the reforms in China's airline industry promoted improvements in airlines' productivity and in their abilities to catch-up and innovate. Kuljanin et al. (2019) documented that while airlines based in central and southeast Europe have demonstrated progress in efficiency, they are still less efficient than their peers that mainly operate in Western Europe.

Regarding the documentation of geographical differentials in airline performance, Arjomandi and Seufert (2014) found that China and North Asia are the homes of many technically efficient airlines, while many of the leading environmentally efficient airlines were from Europe. Employing the slacks-based DEA framework, Chang et al. (2014) revealed that Asian-based airlines are more efficient than airlines based in Europe and America. In a cross-country analysis, Yu et al. (2019) adopted a dynamic network DEA model to evaluate the performance of Chinese and Indian airlines. They revealed that low-cost and privately-owned carriers demonstrated higher efficiency performance than others, thus suggesting the need for continuous reforms in China's air transport industry.

In terms of identifying the factors affecting airlines' operating costs, Lu et al. (2012) showed that low-cost carriers were generally more efficient than full-service network carriers and revealed the considerable role of corporate governance in airline performance. Merkert and Hensher (2011) applied a two-stage DEA method to investigate the origins of airlines' cost efficiency and concluded that airline size and several leading fleet-related characteristics are crucial in successful cost management. Regarding the size of an air 
carrier, Merkert and Morrell (2012) supported the economies of scale argument but cautioned that when airlines' seating capacity passes 200 billion available seat kilometers, it will be difficult for the company to operate efficiently. Zuidberg (2014) also highlighted the importance of economies of density, load factor, aircraft utilization, and aircraft size in airline operations. Wu and Liao (2014) confirmed the advantages of applying DEA models in assessing airlines' performance and emphasized the importance of resource allocation abilities among airlines. The significance of private ownership, a low-cost business model, and weight load were supported in Lee and Worthington (2014).

In a book discussing the efficiency and competitiveness of international airlines, Heshmati and Kim (2016) concluded the following: (1) airlines' efficiency was key to achieving profit maximization; (2) while airline size positively impacted output efficiency, larger airlines were less capable than smaller airlines in reaching better cost efficiency; (3) airlines demonstrated adequate productivity efficiency but were less successful in reaching cost efficiency; and (4) airlines needed to incorporate more cost savings initiatives to further strengthen their global competitiveness. In addition, the focus of research has evolved from earlier efforts that investigated the effect of market deregulations on airline productivity and efficiency to more recent interest in explaining how the different business models and corporate strategies affect airline performance.

While there are many studies on airline efficiency, most focused on operational efficiency. Research connecting operational efficiency to airlines' financial performance is still relatively new. Studies in this developing field include Gramani (2012), Pires and Fernandes (2012), and Zhang et al. (2019). Gramani (2012) used a two-phase DEA model to examine the operational and financial performance of four airlines during 1997-2006 and found that airlines based in emerging markets realized better operational performance than financial performance, indicating the need to improve resource allocation. Pires and Fernandes (2012) analyzed 42 international airlines' financial efficiency and discovered that airlines that focused more on reducing their financial leverage saw improvement in profitability. Zhang et al. (2019) investigated the performance of nine international airlines for 2006-2016 using both operational and financial indicators and found that although low-cost carriers achieved higher scores on operational-based metrics, full-service carriers tended to perform better on equity market indicators.

The review of the literature revealed several important findings. First, the empirical results are sensitive to the choices of the sample selections, reflecting the constantly evolving nature of the airline operating environment. Therefore, a periodic re-examination of the industry's development is necessary. Second, the ultimate goal of a corporation is to maximize its shareholders' wealth. Since improving operating efficiency does not necessarily lead to improved financial efficiency (Gramani, 2012), adding financial metrics in airline performance evaluation helps obtain a deeper understanding of airlines' overall well-being. The two aforementioned observations prompt the investigation in this study.

\section{Research Method and Data}

\section{Research Method}

\section{Two-Stage Network DEA Model}

Regarding airline performance assessment, $\mathrm{Yu}$ (2016) stated that there has been a shift in empirical modeling from index procedures and OLS estimations in the earlier years to DEA approaches in recent years. The popularity of DEA-related models stemmed from the fact that DEA modeling does not require detailed information such as unit costs that are required by traditional methods but are usually not publicly available due to data proprietorship. Moreover, as discussed in Charnes et al. (1994), Cooper et al. (2006) and (2011), the DEA approach offers many advantages in empirical modeling; for example, it requires very few assumptions in functional forms, and it provides a single score to summarize the overall resource utilization. In fact, the use of DEA methods in analyzing airline performance has become a mainstream approach (Yu, 2016), and the transportation sector has been identified as one of the fields in which DEA models are most frequently adopted in empirical studies (Liu et al., 2013), which justifies the use of the DEA structure in the current study.

DEA is a nonparametric approach for calibrating the relative efficiency of an entity, called the decision-making unit (DMU), within a group of peer entities who utilize common inputs to produce common outputs. In their innovative paper, Charnes et al. (1978) demonstrated a mathematical approach that calibrates each DMU's capability of transforming several inputs into multiple outputs and summarizes the results with a single efficiency score. In the DEA calculation, a piecewise linear production frontier is constructed to represent the best-practice production attainable for the DMUs in the sample group. DMUs that lie on the production frontier are regarded as efficient, whereas DMUs that are not on the frontier are inefficient (Cooper et al., 2011; $\mathrm{Yu}, 2016)$. Therefore, the efficiency score derived from the DEA model represents each DMU's relative efficiency. The efficiency score ranges from zero to one, with a score of one representing efficient and a score of less than one indicating inefficient.

Let $j=1, \ldots, n$ be the number of $\mathrm{DMU}_{j}$ in the sample group and the DMU to be evaluated is denoted as $\mathrm{DMU}_{o}$. 
Each DMU consumes different amounts of $m$ inputs $x_{i j}(i=1,2, \ldots, m)$ to produce different levels of $s$ outputs $y_{r j}(r=1,2, \ldots, s)$. The programming problem shown in Charnes et al. (1978) is presented as follows:

$\max \sum_{r=1}^{s} u_{r} y_{r o}$

s.t. $\sum_{r=1}^{s} u_{r} y_{r j}-\sum_{i=1}^{m} v_{i} x_{i j} \leq 0$

$\sum_{i=1}^{m} v_{i} x_{i o}=1$

$u_{r} \geq 0 ; v_{i} \geq 0 ; r=1,2, \ldots, s ; i=1,2, \ldots, m ; j=1,2, \ldots, n$.

In traditional DEA structures, a factor cannot be recognized simultaneously as an input and output in the model (Cook \& Zhu, 2014; Duygun et al., 2016; Kao \& Hwang, 2008; Liang et al., 2008; Mallikarjun, 2015; Tone \& Tsutsui, 2009; Zhu, 2011). Thus, the traditional DEA models ignore the existence of possible linking activities and internal structures between factors in the operating process, treating corporate operations as a "black box." The recently developed two-stage network DEA models, however, address such modeling issues by considering the relational interactions between the divisions within a DMU and allowing the intermediate factors to serve as outputs from the first stage and as the inputs to the second stage. As the operations of an airline company usually involve two stages in realizing marketability measures (Yu et al., 2019), in this study, we adopted an input-oriented two-stage centralized network framework proposed by Liang et al. (2008) to gauge the performance of major US airlines. In our study, the first stage is labeled as operations stage, where resources are used to produce intermediate measures. The intermediate measures then enter into the second stage, referred to as the profitability stage, to generate financial outcomes.

Following the developments and structures in Liang et al. (2008), we assumed there are $m$ inputs $x_{i j}$, where $i=1,2, \ldots, m$; and $H$ outputs $z_{h j}$, where $h=1,2, \ldots, H$, for each $\mathrm{DMU}_{j}$ in the first stage. These $H$ outputs from the first stage, called intermediate measures, are used as the inputs in the second stage in producing the final outputs $y_{r j}$, where $r=1,2, \ldots, s$, of the entire business activity. The efficiency score for the first stage, $E S_{j}^{1}$, and second stage, $E S_{j}^{2}$, can be written as

$E S_{j}^{1}=\frac{\sum_{h=1}^{H} w_{h} z_{h j}}{\sum_{i=1}^{m} v_{i} x_{i j}}$ and $E S_{j}^{2}=\frac{\sum_{r=1}^{s} u_{r} y_{r j}}{\sum_{h=1}^{H} \tilde{w}_{h} z_{h j}}$, respectively, where $v_{i}, u_{r} w_{h}$, and $\tilde{w}_{h}$ are non-negative, unknown weights; and $\tilde{w}_{h}=w_{h}$. According to Liang et al. (2008), the resulting overall efficiency score, $T S_{0}$, for $\mathrm{DMU}_{0}$ is computed as

$T S_{0}=\operatorname{MaxES}_{0}^{1} \bullet E S_{0}^{2}=\frac{\sum_{r=1}^{s} u_{r} y_{r 0}}{\sum_{i=1}^{m} v_{i} x_{i 0}}$

s.t. $E S_{j}^{1} \leq 1$ and $E S_{j}^{2} \leq 1$ and $w_{h}=\tilde{w}_{h}$.

The linear representation of Eq. (3) becomes

$T S_{0}=\operatorname{Max} \sum_{r=1}^{s} u_{r} y_{r 0}$

s.t. $\sum_{r=1}^{s} u_{r} y_{r j}-\sum_{h=1}^{H} w_{h} z_{h j} \leq 0 j=1,2, \cdots, n$

$\sum_{h=1}^{H} w_{h} z_{h j}-\sum_{i=1}^{m} v_{i} x_{i j} \leq 0 j=1,2, \cdots, n$

$\sum_{i=1}^{m} v_{i} x_{i 0}=1$

$w_{h} \geq 0, h=1,2, \cdots H ; v_{i} \geq 0, i=1,2, \cdots m ; u_{r} \geq 0, r=1,2, \cdots s$. Therefore, the efficiency scores for the first and second stages can be expressed as

$E S_{0}^{1}=\frac{\sum_{h=1}^{H} w_{h}^{*} z_{h 0}}{\sum_{i=1}^{m} v_{i}^{*} x_{i 0}}=\sum_{h=1}^{H} w_{h}^{*} z_{h 0}$ and $E S_{0}^{2}=\frac{\sum_{r=1}^{s} u_{r}^{*} y_{r 0}}{\sum_{h=1}^{H} w_{h}^{*} z_{h 0}}$.

In the model developed by Liang et al. (2008), constant returns to scale are assumed, and the overall centralized efficiency score is defined as the product of the efficiency score from stage one and the efficiency score from stage two.

Based on the discussion in Sect. 2, airline-specific measures that are commonly adopted in evaluations are available seat miles (ASM), revenue passenger miles (RPM), cost per available seat mile (CASM), revenue per available seat mile (RASM), and load factor (LF). According to the definitions provided in Vasigh et al. (2015), ASM represents an airline's basic output regardless of whether the seats are filled, and RPM indicates the number of miles that revenue passengers have flown. Therefore, the percentage of an airline's available seats that are filled by revenue passengers, known as LF, is the measure of capacity utilization. While a higher LF indicates better capacity utilization, a high LF does not imply better profitability. In airline analyses, the standardized measures of unit costs and unit revenues are CASM and RASM, respectively. In this study, CASM is used as the input in the first stage. RASM and LF are adopted as the 


\begin{tabular}{|c|c|c|c|c|}
\hline \multirow{2}{*}{ CASM } & \multirow{2}{*}{$\begin{array}{l}\text { Operations } \\
\text { Stage }\end{array}$} & RASM & \multirow{2}{*}{$\begin{array}{c}\text { Profitability } \\
\text { Stage }\end{array}$} & \\
\hline & & LF & & \\
\hline
\end{tabular}

Fig. 1 Two-stage performance evaluation framework

intermediate factors, serving as the outputs for the first stage and as the inputs in the second stage. In the second stage, we chose the return on investment (ROI), defined as the annualized operating income as a percentage of average invested capital, as the measure to evaluate airline profitability. ROI helps companies identify how effectively operating assets are used to generate operating income. ROI is a suitable measure in this context because it reflects the company's basic earning power. According to Cooper et al. (2011), to ensure DEA models' ability to differentiate efficiencies among the DMUs, the minimum sample size a study needs is at least twice the product of the number of outputs and number of inputs. In this study, there is one input and two outputs for the first stage and two inputs and one output for the second stage. Each stage of the model satisfies the requirement to produce differentiable outcomes. Our two-stage performance evaluation framework is illustrated in Fig. 1.

\section{Exploring Factors Impacting Airlines' Overall Efficiency}

While DEA methods are excellent tools for calibrating efficiency, the methods do not explain the causes of inefficiencies among DMUs. Therefore, many empirical studies follow up the DEA results with a truncated regression to explore the influence of environmental variables on DMUs' efficiency. Simar and Wilson (2007) pointed out that employing conventional truncated regressions to examine how exogenous variables affect the resulting non-parametric DMU scores is inadequate because of the serial correlation presented in the estimated DEA scores. They proposed an alternative truncated regression model with bootstrap procedures to resolve the estimation issues. In this study, we employed the model pioneered by Simar and Wilson (2007) with 2000 replications to enhance the robustness of the estimation outcomes. The environmental variables considered are average stage length flown, total assets, fleet size, and full-time employee equivalents. The average stage length flown is defined as total aircraft miles flown divided by total aircraft departures. The inclusion of this variable helps to identify how airlines' route planning decisions, many of which are the results of the business model adopted, affect attainable efficiency. Total assets are used to gauge whether the size of an airline could be an obstacle in reaching efficiency optimality, as indicated in Merkert and Morrell (2012). Fleet size and fulltime employee equivalents are included to reflect the needs for capital and labor in routine operations. Fuel expenses, while being the largest component of operating expenses, are not included as one of the environmental variables for two reasons. First, the price of fuel is a systemic factor that affects all carriers in the market. Therefore, the impact of fuel prices is universal, rather than a company-specific variable. Thus, fuel expenses are not ideal in identifying efficiency differences in the current context. Second, while airlines may engage in fuel hedging to reduce their financial risk exposure, the empirical results show that fuel hedging is ineffective (Berghöfer \& Lucey, 2014). Therefore, some airlines have abolished fuel hedging in recent years.

\section{Data}

To analyze the nine U.S. airlines' performance during 2015-2019, we collected yearly traffic and financial data from the MIT Airline Data Project and Mergent Online. According to their business models, the nine airlines under evaluation can be further classified into two categories: full-service network carriers (FSCs) and low-cost carriers (LCCs). The full-service network carriers analyzed were American Airlines (AA), Delta Air Lines (DL), United Airlines (UA), Alaska Airlines (AS), and Hawaiian Airlines (HA); and the low-cost carriers were JetBlue Airways (B6), Southwest Airlines (WN), Spirit Airlines (NK), and Allegiant Air (G4). According to Table 2, while the capacity utilization (represented by the load factor) and the unit revenues (indicated by RASM) remain stable, the unit costs (represented by CASM) increase over the years. The average ROI from the sample airlines shows a downward trend. The average sizes of the carrier, labor force, and fleet have grown over the years, while the average stage length flown has remained approximately the same.

\section{Empirical Results}

Table 3 illustrates the results of the two-stage centralized network DEA model. Figures 2, 3, and 4 depict the average efficiency scores from the two-stage centralized network DEA models for all carriers, full-service network carriers, and low-cost carriers, respectively.

For all carriers analyzed, the overall average efficiency score ranged from 0.599 to 0.671 for 2015-2018 and spiked to 0.759 in 2019 . The first stage average efficiency shows a persistent increase over time, demonstrating a steady convergence to operating efficiency among carriers. However, the average efficiency score from the second stage reveals the challenges many carriers faced as it remains at 0.8 or lower over the years. This result confirms Gramani's (2012) view that improving operations does not lead to elevated financial performance. As the ultimate goal for corporate operations is to maximize shareholders' wealth and room for further 
Table 2 Descriptive statistics of variables from nine U.S. airlines for 2015-2019

\begin{tabular}{|c|c|c|c|c|c|c|c|}
\hline Variables & & & 2015 & 2016 & 2017 & 2018 & 2019 \\
\hline \multirow[t]{4}{*}{ Input } & \multirow[t]{4}{*}{ CASM (Cents per ASM) } & $\operatorname{Max}$ & 12.68 & 12.27 & 12.92 & 13.92 & 14.09 \\
\hline & & Min & 7.64 & 7.33 & 7.64 & 8.19 & 7.96 \\
\hline & & Avg & 10.51 & 10.27 & 10.92 & 11.58 & 11.50 \\
\hline & & S.D & 1.71 & 1.81 & 1.78 & 1.89 & 2.03 \\
\hline \multirow[t]{8}{*}{ Intermediate } & \multirow[t]{4}{*}{ RASM (Cents per ASM) } & $\operatorname{Max}$ & 15.07 & 14.39 & 14.74 & 15.16 & 15.67 \\
\hline & & Min & 10.02 & 9.06 & 8.93 & 9.14 & 9.14 \\
\hline & & Avg & 12.59 & 11.99 & 12.19 & 12.43 & 12.67 \\
\hline & & S.D & 1.67 & 1.82 & 1.99 & 2.15 & 2.18 \\
\hline & \multirow[t]{4}{*}{ Load factor } & $\operatorname{Max}$ & 0.87 & 0.85 & 0.86 & 0.86 & 0.87 \\
\hline & & Min & 0.81 & 0.82 & 0.82 & 0.83 & 0.84 \\
\hline & & Avg & 0.84 & 0.84 & 0.84 & 0.84 & 0.85 \\
\hline & & S.D & 0.01 & 0.01 & 0.01 & 0.01 & 0.01 \\
\hline \multirow[t]{4}{*}{ Output } & \multirow[t]{4}{*}{ ROI } & $\operatorname{Max}$ & 0.43 & 0.36 & 0.35 & 0.23 & 0.23 \\
\hline & & Min & 0.25 & 0.19 & 0.14 & 0.05 & 0.12 \\
\hline & & Avg & 0.35 & 0.28 & 0.21 & 0.14 & 0.17 \\
\hline & & S.D & 0.07 & 0.06 & 0.08 & 0.06 & 0.04 \\
\hline \multirow[t]{16}{*}{ Environmental } & \multirow[t]{4}{*}{ Avg. Stage Length Flown } & Max & 1684 & 1633 & 1589 & 1582 & 1597 \\
\hline & & Min & 750 & 760 & 754 & 757 & 748 \\
\hline & & Avg & 1093 & 1089 & 1086 & 1104 & 1109 \\
\hline & & S.D & 276 & 261 & 253 & 250 & 251 \\
\hline & \multirow[t]{4}{*}{ Total Assets (Thousands) } & Max & $53,134,000$ & $51,274,000$ & $53,292,000$ & $60,580,000$ & $64,532,000$ \\
\hline & & Min & $1,351,662$ & $1,671,576$ & $2,180,157$ & $2,498,668$ & $3,010,803$ \\
\hline & & Avg & $20,589,657$ & $21,438,012$ & $22,425,438$ & $24,897,752$ & $26,902,760$ \\
\hline & & S.D & $21,236,336$ & $20,866,197$ & $21,267,951$ & $24,209,450$ & $25,186,756$ \\
\hline & \multirow[t]{4}{*}{ Fleet Size } & Max & 972 & 936 & 947 & 925 & 884 \\
\hline & & Min & 48 & 49 & 51 & 56 & 58 \\
\hline & & Avg & 408 & 417 & 430 & 442 & 445 \\
\hline & & S.D & 370 & 366 & 370 & 363 & 354 \\
\hline & \multirow[t]{4}{*}{ Full-Time Employee } & Max & 98,885 & 101,504 & 103,101 & 102,942 & 104,216 \\
\hline & & Min & 2546 & 3146 & 3433 & 3904 & 4140 \\
\hline & & Avg & 39,050 & 40,914 & 41,960 & 43,207 & 44,364 \\
\hline & & S.D & 39,563 & 40,706 & 40,475 & 40,330 & 41,130 \\
\hline
\end{tabular}

The airlines studied are American Airlines (AA), Delta Air Lines (DL), United Airlines (UA), Alaska Airlines (AS), Hawaiian Airlines (HA), JetBlue Airways (B6), Southwest Airlines (WN), Spirit Airlines (NK), and Allegiant Air (G4)

improvement in the operations stage is limited among carriers, our empirical findings disclose that companies may see more visible breakthroughs in the overall efficiency if attention is given to the profitability stage, where resource allocation becomes vital. To enhance a corporation's profitability, companies may review their business factors, such as the sources and the degree of diversity in revenue structures, the marginal benefits of acquiring fuel-efficient aircraft in cost management, and the availability of alternative funding channels such as secured/unsecured debts or enhanced equipment trust certificates (EETCs).

Among all carriers, Spirit Airlines had the highest frequency of reaching the efficiency score of one, which was related to its performance in the operations stage. In contrast, American Airlines, United Airlines, and JetBlue Airways were the three carriers with no occurrence of full efficiency in either the first or second stage. When examining the performance of the two subgroups, full-service carriers, and low-cost carriers, we noticed that while there were individual differences, full-service carriers, on average, were less efficient than their peers operating in the low-cost business models. Nevertheless, since full-service carriers were less efficient in both stages of corporate activities, fullservice carriers would find it easier to reallocate resources to boost efficiency (Duygun et al., 2016).

To identify the determinants of airlines' efficiency, the truncated regression model developed by Simar and Wilson (2007) was implemented. Variables such as the average stage 
Table 3 Summary of the efficiency scores from the two-stage centralized DEA model

\begin{tabular}{|c|c|c|c|c|c|c|c|c|c|c|c|c|c|c|c|}
\hline \multirow[t]{2}{*}{ DMU } & \multicolumn{3}{|l|}{2015} & \multicolumn{3}{|l|}{2016} & \multicolumn{3}{|l|}{2017} & \multicolumn{3}{|l|}{2018} & \multicolumn{3}{|l|}{2019} \\
\hline & Total & Stage 1 & Stage 2 & Total & Stage 1 & Stage 2 & Total & Stage 1 & Stage 2 & Total & Stage 1 & Stage 2 & Total & Stage 1 & Stage 2 \\
\hline \multicolumn{16}{|l|}{ FSC } \\
\hline AA & 0.442 & 0.740 & 0.598 & 0.373 & 0.816 & 0.457 & 0.347 & 0.836 & 0.416 & 0.356 & 0.894 & 0.398 & 0.452 & 0.906 & 0.499 \\
\hline DL & 0.641 & 0.751 & 0.854 & 0.666 & 0.876 & 0.760 & 0.704 & 0.925 & 0.761 & 0.735 & 0.954 & 0.771 & 0.872 & 1.000 & 0.872 \\
\hline UA & 0.475 & 0.717 & 0.662 & 0.402 & 0.786 & 0.512 & 0.411 & 0.816 & 0.503 & 0.519 & 0.843 & 0.616 & 0.654 & 0.864 & 0.757 \\
\hline AS & 0.876 & 0.876 & 1.000 & 0.758 & 1.000 & 0.758 & 0.680 & 1.000 & 0.680 & 0.495 & 0.936 & 0.529 & 0.863 & 0.958 & 0.901 \\
\hline HA & 0.607 & 0.802 & 0.757 & 0.670 & 0.882 & 0.760 & 0.967 & 0.967 & 1.000 & 0.802 & 0.935 & 0.858 & 0.792 & 0.935 & 0.847 \\
\hline \multicolumn{16}{|l|}{ LCC } \\
\hline B6 & 0.462 & 0.815 & 0.566 & 0.578 & 0.928 & 0.622 & 0.514 & 0.907 & 0.566 & 0.200 & 0.907 & 0.221 & 0.527 & 0.914 & 0.576 \\
\hline WN & 0.730 & 0.816 & 0.894 & 0.688 & 0.923 & 0.745 & 0.750 & 0.975 & 0.769 & 1.000 & 1.000 & 1.000 & 0.942 & 0.981 & 0.960 \\
\hline NK & 0.871 & 1.000 & 0.871 & 0.656 & 1.000 & 0.656 & 0.574 & 0.948 & 0.605 & 0.591 & 1.000 & 0.591 & 0.763 & 1.000 & 0.763 \\
\hline G4 & 0.932 & 0.932 & 1.000 & 0.930 & 0.930 & 1.000 & 0.511 & 0.799 & 0.640 & 0.695 & 0.876 & 0.793 & 0.966 & 0.966 & 1.000 \\
\hline Median & 0.641 & 0.815 & 0.854 & 0.666 & 0.923 & 0.745 & 0.574 & 0.925 & 0.640 & 0.591 & 0.935 & 0.616 & 0.792 & 0.958 & 0.847 \\
\hline \multicolumn{16}{|l|}{ Average } \\
\hline ALL & 0.671 & 0.828 & 0.800 & 0.636 & 0.905 & 0.697 & 0.606 & 0.908 & 0.660 & 0.599 & 0.927 & 0.642 & 0.759 & 0.947 & 0.797 \\
\hline FSC & 0.608 & 0.777 & 0.774 & 0.574 & 0.872 & 0.649 & 0.622 & 0.909 & 0.672 & 0.582 & 0.913 & 0.634 & 0.726 & 0.932 & 0.775 \\
\hline LCC & 0.749 & 0.891 & 0.833 & 0.713 & 0.945 & 0.756 & 0.587 & 0.907 & 0.645 & 0.622 & 0.946 & 0.651 & 0.799 & 0.965 & 0.825 \\
\hline
\end{tabular}

The carriers under full-service network (FSC) category are American Airlines (AA), Delta Air Lines (DL), United Airlines (UA), Alaska Airlines (AS), and Hawaiian Airlines (HA). Low-cost carriers (LCC) include JetBlue Airways (B6), Southwest Airlines (WN), Spirit Airlines (NK), and Allegiant Air (G4). Stage 1 is the operations stage and stage 2 is the profitability stage

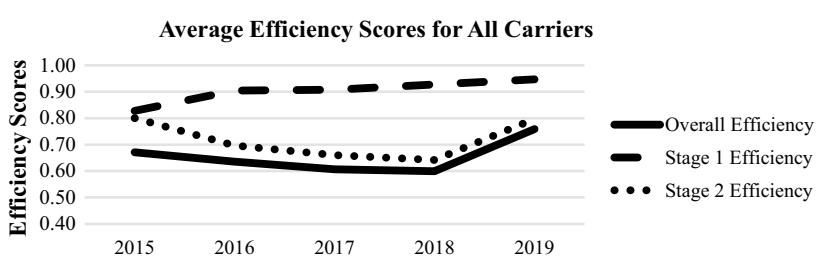

Fig. 2 Average efficiency scores for all carriers

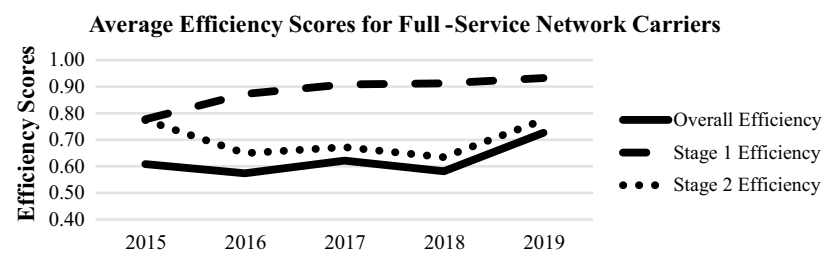

Fig. 3 Average efficiency scores for full-service network carriers

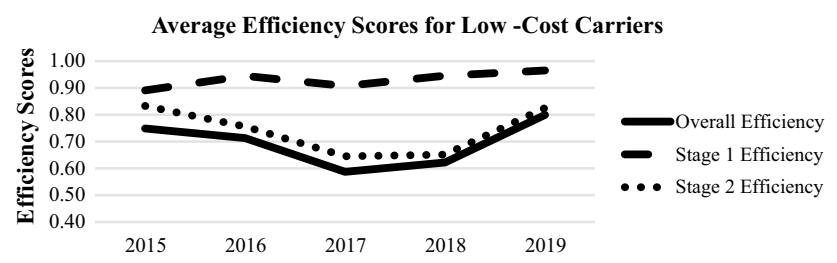

Fig. 4 Average efficiency scores for low-cost carriers length flown, total assets, fleet size, and full-time employee equivalents were converted into their logarithmic transformations to rescale the data. Table 4 reports the regression results from regressing the efficiency scores of the operations and profitability stages on the environmental variables.

According to Table 4, the average stage length flown is statistically significant in both the operations and profitability stages. Specifically, the longer the average stage length flown is, the lower the efficiency scores. Since the average stage length is related to an airline's network planning and its business model, the empirical results reiterate the role of business models in an airline's ability to attain efficiency. Our results confirm earlier findings (Barros \& Peypoch, 2009; Lu et al., 2012; Barros \& Couto, 2013; Lee \& Worthington, 2014; Duygun et al., 2016; and Yu et al., 2019) that low-cost carriers, whose operations are mainly short-haul services, are more efficient because of their cost structures. Moreover, low-cost carriers' operating models allow them to adapt their operations more easily to changes in market demands. As discussed in Vasigh et al. (2015), the proliferation of low-cost carriers is one of the major developments in the U.S. airline industry since the industry's deregulation in 1978. The competition brought by these low-cost carriers has put tremendous financial pressure on full-service network carriers. However, it is important to note that while low-cost carriers achieved higher efficiency and profitability, the aggregate revenues, in dollars, realized by full-service carriers still exceeded those realized by low-cost carriers due 
Table 4 Truncated bootstrapped regressions

\begin{tabular}{|c|c|c|c|c|c|c|}
\hline \multirow[t]{2}{*}{ Variables } & \multicolumn{3}{|c|}{ Operations stage } & \multicolumn{3}{|c|}{ Profitability stage } \\
\hline & Coefficient & $\begin{array}{l}\text { Bootstrap } \\
\text { Std. Error }\end{array}$ & $P>|\mathrm{z}|$ & Coefficient & $\begin{array}{l}\text { Bootstrap } \\
\text { Std. Error }\end{array}$ & $P>|z|$ \\
\hline ln (Stage length) & $-0.258 * * *$ & 0.089 & 0.004 & $-0.627 * * *$ & 0.200 & 0.002 \\
\hline $\ln$ (Total assets) & $0.324 * * *$ & 0.124 & 0.009 & 0.159 & 0.215 & 0.458 \\
\hline $\ln ($ Fleet size $)$ & -0.072 & 0.069 & 0.299 & -0.129 & 0.150 & 0.387 \\
\hline ln (Full-time employee) & $-0.267 * *$ & 0.111 & 0.017 & -0.044 & 0.206 & 0.831 \\
\hline Constant & 0.516 & 0.791 & 0.514 & $3.672 * *$ & 1.593 & 0.021 \\
\hline Sigma & 0.077 & 0.013 & 0.000 & 0.175 & 0.026 & 0.000 \\
\hline
\end{tabular}

Results from two truncated bootstrapped regressions are reported, one for the operations stage (first stage) and one for the profitability stage (second stage). In each regression, the respective stage's efficiency score is the dependent variable, and the environmental variables are the independent variables. There are 2000 bootstrap replications for each regression

$* * *$ Significance at $1 \%$ level

$* *$ Significance at $5 \%$ level to full-service carriers' broader operating scopes and market capitalization. In fact, the two business models see disparate operating outcomes and advantages under different states of the economy. Full-service carriers are naturally at an advantage in generating greater profits when the broader economy is strong. Low-cost carriers are better off when the demands are volatile and the competition is mainly cost-driven.

Our regression results also indicated that the size of airlines, approximated by total assets, promotes higher operating efficiency, indicating the importance of reaching economies of scale (Heshmati \& Kim, 2016) and confirming the arguments that recent mergers have yielded a procompetitive effect (Carlton et al., 2019). On the other hand, the empirical results show that the size of full-time employee equivalents exhibited a negative relationship to operating efficiency, indicating that high labor-related costs continue to hinder airlines' ability to attain increased efficiency. In the airline industry, labor costs are the second largest operating cost item, and a considerable portion of labor costs are fixed costs in the short term. Since it is not uncommon to see inefficiency in the labor force when the business environment is highly regulated, how to improve labor efficiency, as measured by revenue generated per employee, becomes an immediate task with which carriers should contend.

\section{Conclusion}

This study analyzed the recent operating and financial performance of nine U.S. airlines in 2015-2019. The U.S. airline industry has changed dramatically since the mega-mergers that occurred from 2008 to 2013 . Therefore, a timely investigation is needed to understand the current dynamics in the industry and to identify ways to sustain airlines' longterm financial prosperity.
Empirically, airline performance is frequently examined via DEA models. However, traditional DEA models treat the production process as a single "black box" and cannot address the interactions between different production stages within a corporate entity. In this study, we employed the two-stage centralized network DEA model proposed by Liang et al. (2008) to compartmentalize the total efficiency into two segments: operating efficiency and the efficiency in achieving profitability. A truncated regression was conducted to analyze the causes of the realized efficiency scores. Our empirical results reveal several findings. First, the operating efficiency in the U.S. airline industry has shown steady advancement, but the efficiency of the profitability stage remains to be improved. To ameliorate the efficiency in the profitability stage, companies may review their resource allocation strategies in revenue structures, cost management, and the availability of different funding alternatives. Second, on average, airlines operating in the low-cost business model yielded higher efficiency in both operations and financial performance. The role of business models in an airline's ability to attain efficiency is reasserted. Third, airlines' size, in terms of total assets, has been shown to positively promote efficiency in operations, but the size of the labor force has demonstrated a negative impact on firms' operating efficiency.

The onset of the recent global COVID-19 pandemic has caused a catastrophe in the airline industry's operations and financial stability. As many corporate reconstructions and consolidations among airlines are expected in the coming years, the empirical findings in this paper identify areas that could be considered when making strategic resource allocation decisions. 


\section{Key Questions Reflecting Applicability in Real Life}

1. What are the factors affecting airlines' performance?

2. Has the efficiency of US airlines improved after the wave of recent airline mergers?

3. What are the causes of inefficiencies among airlines?

4. How do the differences in each business model affect airlines' operating and financial performance?

Acknowledgements We would like to express our great appreciation to the editors and anonymous reviewers for their constructive suggestions, which helped to improve the quality of this manuscript.

Funding The authors did not receive any funding for this study.

Availability of Data and Material Publicly available data.

\section{Declarations}

Conflict of interest There is no conflict of interest in this study.

\section{References}

Arjomandi, A., \& Seufert, J. H. (2014). An evaluation of the world's major airlines' technical and environmental performance. Economic Modelling, 41, 133-144. https://doi.org/10.1016/j.econm od.2014.05.002

Barros, C. P., \& Couto, E. (2013). Productivity analysis of European airlines, 2000-2011. Journal of Air Transport Management, 31, 11-13. https://doi.org/10.1016/j.jairtraman.2012.10.006

Barros, C. P., \& Peypoch, N. (2009). An evaluation of European airlines' operational performance. International Journal of Production Economics, 122(2), 525-533. https://doi.org/10.1016/j.ijpe. 2009.04.016

Barros, C. P., Liang, Q. B., \& Peypoch, N. (2013). The technical efficiency of US Airlines. Transportation Research Part a Policy and Practice, 50, 139-148. https://doi.org/10.1016/j.tra.2013.01.019

Berghöfer, B., \& Lucey, B. (2014). Fuel hedging, operational hedging and risk exposure - evidence from the global airline industry. International Review of Financial Analysis, 34, 124-139. https:// doi.org/10.1016/j.irfa.2014.02.007

Carlton, D., Israel, M., MacSwain, I., \& Orlov, E. (2019). Are legacy airline mergers pro- or anti-competitive? Evidence from recent U.S. airline mergers. International Journal of Industrial Organization, 62, 58-95. https://doi.org/10.1016/j.ijindorg.2017.12.002

Chang, Y. T., Park, H., Jeong, J., \& Lee, J. (2014). Evaluating economic and environmental efficiency of global airlines: a SBMDEA approach. Transportation Research Part d Transport and Environment, 27, 46-50. https://doi.org/10.1016/j.trd.2013.12.013

Charnes, A., Cooper, W. W., \& Rhodes, E. (1978). Measuring the efficiency of decision making units. European Journal of Operational Research, 2(6), 429-444. https://doi.org/10.1016/0377-2217(78) 90138-8

Charnes, A., Cooper, W. W., Lewin, A. Y., \& Seiford, L. M. (1994). Data envelopment analysis: Theory, methodology, and applications. Kluwer Academic Publishers (Springer). https://doi.org/10. 1007/978-94-011-0637-5
Chen, Z., Rose, A. Z., Prager, F., \& Chatterjee, S. (2017). Economic consequences of aviation system disruptions: a reduced-form computable general equilibrium analysis. Transportation Research Part a: Policy and Practice, 95, 207-226. https://doi.org/10. 1016/j.tra.2016.09.027

Chen, Z., Tzeremes, P., \& Tzeremes, N. G. (2018). Convergence in the Chinese airline industry: a Malmquist productivity analysis. Journal of Air Transport Management, 73(April), 77-86. https:// doi.org/10.1016/j.jairtraman.2018.08.010

Choi, K. (2017). Multi-period efficiency and productivity changes in US domestic airlines. Journal of Air Transport Management, 59, 18-25. https://doi.org/10.1016/j.jairtraman.2016.11.007

Cook, W., \& Zhu, J. (2014). Data envelopment analysis: a handbook on the modeling of internal structures and networks. Springer. https://doi.org/10.1007/978-1-4899-8068-7

Cooper, W. W., Seiford, L. M., \& Tone, K. (2006). Introduction to data envelopment analysis and its uses: with DEA-Solver software and references. Springer. https://doi.org/10.1007/0-387-29122-9

Cooper, W. W., Seiford, L., \& Zhu, J. (Eds.). (2011). Handbook on data envelopment analysis. Springer. https://doi.org/10.1007/ 978-1-4419-6151-8

Corbet, S., O’Connell, J. F., Efthymiou, M., Guiomard, C., \& Lucey, B. (2019). The impact of terrorism on European tourism. Annals of Tourism Research, 75, 1-17. https://doi.org/10.1016/j.annals. 2018.12.012

Dube, K., Nhamo, G., \& Chikodzi, D. (2021). COVID-19 pandemic and prospects for recovery of the global aviation industry. Journal of Air Transport Management. https://doi.org/10.1016/j.jairt raman.2021.102022

Duygun, M., Prior, D., Shaban, M., \& Tortosa-Ausina, E. (2016). Disentangling the European airlines efficiency puzzle: a network data envelopment analysis approach. Omega (united Kingdom), 60, 2-14. https://doi.org/10.1016/j.omega.2015.06.004

Goodrich, J. (2002). September 11, 2001 attack on America: a record of the immediate impacts and reactions in the USA travel and tourism industry. Tourism Management, 23(6), 573-580. https:// doi.org/10.1016/S0261-5177(02)00029-8

Gramani, M. C. N. (2012). Efficiency decomposition approach: a crosscountry airline analysis. Expert Systems with Applications, 39(5), 5815-5819. https://doi.org/10.1016/j.eswa.2011.11.086

Greer, M. R. (2008). Nothing focuses the mind on productivity quite like the fear of liquidation: changes in airline productivity in the United States, 2000-2004. Transportation Research Part a: Policy and Practice, 42(2), 414-426. https://doi.org/10.1016/j.tra.2007. 11.001

Heshmati, A., \& Kim, J. (2016). Efficiency and competitiveness of international airlines. Springer. https://doi.org/10.1007/ 978-981-10-1017-0

Huang, C. C., Hsu, C. C., \& Flouris, T. (2019). Review of recent legacy airline mergers in the U.S.: an empirical study from investors' perspectives. The Journal of Applied Business and Economic, 21(3), 53-64. https://doi.org/10.33423/jabe.v21i3.2080

IATA. (2020). World Air Transport Statistics, Plus Edition 2020 (Report \#8288-64).

Inglada, V., \& Rey, B. (2004). Spanish air travel and the September 11 terrorist attacks: a note. Journal of Air Transport Management, 10(6), 441-443. https://doi.org/10.1016/j.jairtraman.2004.06.002

Janić, M. (2019). Modeling the resilience of an airline cargo transport network affected by a large scale disruptive event. Transportation Research Part d: Transport and Environment, 77, 425-448. https://doi.org/10.1016/j.trd.2019.02.011

Kao, C., \& Hwang, S. N. (2008). Efficiency decomposition in two-stage data envelopment analysis: an application to non-life insurance companies in Taiwan. European Journal of Operational Research, 185(1), 418-429. https://doi.org/10.1016/j.ejor.2006.11.041 
Karakoc, T. H., Colpan, C. O., Altuntas, O., \& Sohret, Y. (2019). Sustainable Aviation. Springer International Publishing. https:// doi.org/10.1007/978-3-030-14195-0

Kuljanin, J., Kalić, M., Caggiani, L., \& Ottomanelli, M. (2019). A comparative efficiency and productivity analysis: implication to airlines located in Central and South-East Europe. Journal of Air Transport Management, 78(January), 152-163. https://doi. org/10.1016/j.jairtraman.2019.01.009

Kumar, B. R. (2012). Mergers and acquisitions in the airline industry. In: Mega Mergers and Acquisitions. Palgrave Macmillan. https://doi.org/10.1057/9781137005908_11

Lee, B. L., \& Worthington, A. C. (2014). Technical efficiency of mainstream airlines and low-cost carriers: New evidence using bootstrap data envelopment analysis truncated regression. Journal of Air Transport Management, 38, 15-20. https://doi.org/10. 1016/j.jairtraman.2013.12.013

Liang, L., Cook, W. D., \& Zhu, J. (2008). DEA models for twostage processes: game approach and efficiency decomposition. Naval Research Logistics, 55(7), 643-653. https://doi.org/10. 1002/nav.2030

Liu, J. S., Lu, L. Y. Y., Lu, W., \& Lin, B. J. Y. (2013). A survey of DEA applications. Omega (united Kingdom), 41(5), 893-902. https://doi.org/10.1016/j.omega.2012.11.004

Lu, W. M., Wang, W. K., Hung, S. W., \& Lu, E. T. (2012). The effects of corporate governance on airline performance: production and marketing efficiency perspectives. Transportation Research Part e Logistics and Transportation Review, 48(2), 529-544. https://doi.org/10.1016/j.tre.2011.09.003

Mallikarjun, S. (2015). Efficiency of US airlines: a strategic operating model. Journal of Air Transport Management, 43, 46-56. https://doi.org/10.1016/j.jairtraman.2014.12.004

Merkert, R., \& Hensher, D. A. (2011). The impact of strategic management and fleet planning on airline efficiency - a random effects Tobit model based on DEA efficiency scores. Transportation Research Part a Policy and Practice, 45(7), 686-695. https://doi.org/10.1016/j.tra.2011.04.015

Merkert, R., \& Morrell, P. S. (2012). Mergers and acquisitions in aviation - management and economic perspectives on the size of airlines. Transportation Research Part e: Logistics and Transportation Review, 48(4), 853-862. https://doi.org/10.1016/j.tre. 2012.02.002

Mitra, D., Pham, C. S., \& Bandyopadhyay, S. (2018). Terrorism and international air travel: a gravity approach. The World Economy, 41(11), 2852-2882. https://doi.org/10.1111/twec.12680

Pearce, B. (2012). The state of air transport markets and the airline industry after the great recession. Journal of Air Transport Management, 21, 3-9. https://doi.org/10.1016/j.jairtraman. 2011.12.011

Pires, H. M., \& Fernandes, E. (2012). Malmquist financial efficiency analysis for airlines. Transportation Research Part e: Logistics and Transportation Review, 48(5), 1049-1055. https://doi.org/ 10.1016/j.tre.2012.03.007

Sadi, M. A., \& Henderson, J. C. (2000). The Asian economic crisis and the aviation industry: impacts and response strategies. Transport Reviews, 20(3), 347-367. https://doi.org/10.1080/ 014416400412841

Simar, L., \& Wilson, P. W. (2007). Estimation and inference in twostage, semi-parametric models of production processes. Journal of Econometrics, 136(1), 31-64. https://doi.org/10.1016/j.jecon om.2005.07.009
Sledsens, T. (1998). Sustainable aviation: The need for a European environmental aviation charge. Transport and Environment, European Federation for Transport and Environment, Brussels 98(1). https://www.transportenvironment.org/publicatio ns/sustainable-aviation-need-european-environmental-aviat ion-charge-te-9801

Sun, X., Wandelt, S., Zheng, C., \& Zhang, A. (2021). COVID-19 pandemic and air transportation: successfully navigating the paper hurricane. Journal of Air Transport Management, 94, 102062. https://doi.org/10.1016/j.jairtraman.2021.102062

Tone, K., \& Tsutsui, M. (2009). Network DEA: a slacks-based measure approach. European Journal of Operational Research, 197(1), 243-252. https://doi.org/10.1016/j.ejor.2008.05.027

Vasigh, B., Fleming, K., \& Humphreys, B. (2015). Foundations of airline finance: methodology and practice. Routledge. https://doi. org/10.4324/9781315813769

Wu, W. Y., \& Liao, Y. K. (2014). A balanced scorecard envelopment approach to assess airlines' performance. Industrial Management and Data Systems, 114(1), 123-143. https://doi.org/10.1108/ IMDS-03-2013-0135

Yu, C. (2016). Airline productivity and efficiency: concept, measurement, and applications. In J. Bitzan, J. Peoples, \& W. Wilson (Eds.), Airline Efficiency (pp. 11-53). Emerald Group Publishing Limited. https://doi.org/10.1108/S2212-160920160000005002

Yu, H., Zhang, Y., Zhang, A., Wang, K., \& Cui, Q. (2019). A comparative study of airline efficiency in China and India: a dynamic network DEA approach. Research in Transportation Economics, 76(September), 100746. https://doi.org/10.1016/j.retrec.2019.100746

Zhang, Q., Koutmos, D., Chen, K., \& Zhu, J. (2019). Using operational and stock analytics to measure airline performance: a network DEA approach. Decision Sciences. https://doi.org/10.1111/deci.12363

Zhu, J. (2011). Airlines performance via two-stage network DEA approach. Journal of CENTRUM Cathedra THe Business and Economics Research Journal, 4(2), 260-269. https://doi.org/10. 7835/jcc-berj-2011-0063

Zuidberg, J. (2014). Identifying airline cost economies: an econometric analysis of the factors affecting aircraft operating costs. Journal of Air Transport Management, 40, 86-95. https://doi.org/10.1016/j. jairtraman.2014.06.007

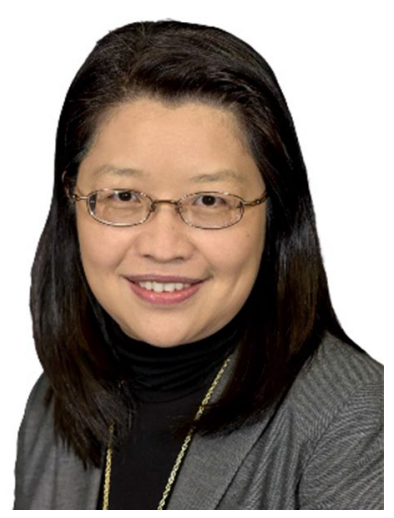

Carol C. Huang is an Associate Professor of Finance at the Ancell School of Business at Western Connecticut State University. She earned a Ph.D. in Financial Economics from The Graduate Center, The City University of New York. Her research interests include portfolio optimization, investors behaviors, and airline finance. She has presented research papers at academic conferences, and her research has appeared in many scholarly journals. Her work has been cited in several well-known journals. Dr. Huang is the author of two book chapters on international diversification and portfolio optimization. Dr. Huang received several grants for academic research and curriculum development. 


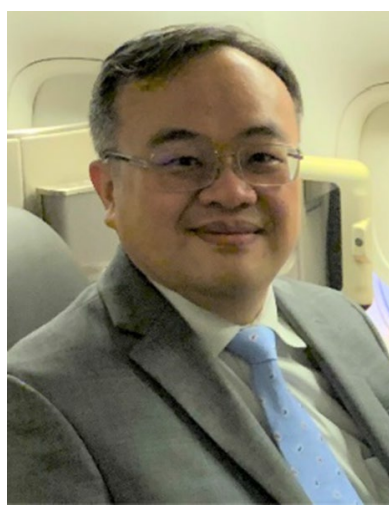

Chris C. Hsu is Professor of Finance, Director of CUNY Aviation Institute, and Chairperson of the Department of Accounting and Finance of York College, The City University of New York. Dr. Hsu's research interests are in quantitative finance and airline finance. $\mathrm{He}$ has published research papers in many academic journals and well-acknowledged handbooks. In addition, he has delivered many presentations at conferences and was invited to give speeches domestically and internationally. Dr. Hsu has been awarded the Golden Key medal and has been acknowledged as a lifetime member of Beta Gamma Sigma, the highest recognition of AACSB International.

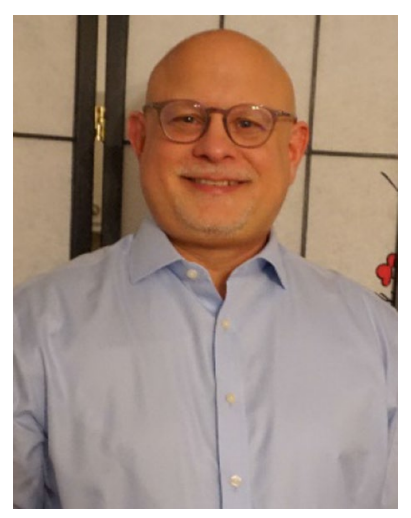

Emilio Collar is a Professor of MIS at Western CT State University and holds a BBA and MS in Information Systems from Pace University (NY) and a PhD from the University of Colorado (Boulder). Emilio's professional experience includes software implementation of Oracle databases, Internet website development, Internet security and planning, and was a technology consultant for IBM at the 1998 Nagano and 2000 Sydney Olympic Games. Emilio has published papers in academic journals including Cybernetics and Informatics, International Journal of Computer Science and Information Security, International Journal of Management Science and Business Administration, Journal of Management and Business Research, and Journal of Systemics. 